\title{
Winter observations of a group of female and immature sperm whales in the high-latitude waters near the Aleutian Islands, Alaska
}

\author{
HOLLY FEARNBACH ${ }^{1}$, JOHN W. DURBAN ${ }^{1,2}$, SALLY A. MIZROCH ${ }^{1}$, STEVE BARBEAUX ${ }^{3}$ AND PAUL R. WADE ${ }^{1}$ \\ ${ }^{1}$ National Marine Mammal Laboratory, Alaska Fisheries Science Center, National Marine Fisheries Service, National Oceanic and \\ Atmospheric Administration, 7600 Sand Point Way NE, Seattle, WA 98115, USA, ${ }^{2}$ Protected Resources Division, Southwest \\ Fisheries Science Center, National Marine Fisheries Service, National Oceanic and Atmospheric Administration, 8604 La Jolla Shores \\ Drive, La Jolla, California 92037, USA, ${ }^{3}$ Resource Ecology and Fisheries Management Division, Alaska Fisheries Science Center, \\ National Marine Fisheries Service, National Oceanic and Atmospheric Administration, 7600 Sand Point Way NE, Seattle, \\ WA 98115, USA
}

\begin{abstract}
Sperm whales (Physeter macrocephalus) have one of the most extensive global distributions of any cetacean, but distribution and movement patterns vary significantly between sexes. Adult male sperm whales are predominantly solitary and have an expansive distribution, whereas females and their offspring typically form groups of both sexes, remaining in the tropics and sub-tropics throughout the year. Here we present observations and photographs from a rare winter sighting of a group of female and immature sperm whales near Koniuji Island, in the Central Aleutians, in the high-latitude waters of the Bering Sea. This sighting is consistent with historic whaling catches of sperm whales of both sexes, including pregnant females, above $50^{\circ} \mathrm{N}$ in the North Pacific, but no groups of females and immatures have been observed in ten years of summer sighting surveys in the Aleutian Islands and Bering Sea region, despite regular sightings of adult males. We discuss possible reasons for the absence of recent sightings of these mixed schools.
\end{abstract}

Keywords: sperm whale, Physeter macrocephalus, females and immatures, distribution

Submitted 25 October 2011; accepted 4 November 2011

Sperm whales (Physeter macrocephalus) have one of the most extensive global distributions of any cetacean (Rice, 1989), but distribution and movement patterns vary significantly between sexes (Whitehead, 2003). Adult male sperm whales are predominantly solitary and have an extensive distribution (Best, 1979; Rice, 1989), typically feeding in higher latitudes and undertaking extensive north-south seasonal movements to tropical or sub-tropical waters to breed (Rice, 1989; Whitehead, 2003). In contrast, females and their offspring typically form stable groups, often comprised of matrilineally related whales of both sexes (Mesnick, 2001; Whitehead, 2003, 2008). These mixed groups of females and immatures appear to have a more restricted range, typically remaining in the tropics and sub-tropics throughout the year (Rice, 1989; Whitehead, 2003; Gero et al., 2007). Based on photoidentification studies, however, some large scale movements (up to $3800 \mathrm{~km}$ ) have been documented for female sperm whales (Jacquet et al., 2003; Whitehead et al., 2008).

In the North Pacific, adult male sperm whales are sighted during summer in the Gulf of Alaska, Bering Sea and waters around the Aleutian Islands (Angliss \& Allen, 2010). Acoustic surveys have detected male sperm whales year round in the Gulf of Alaska, but they appear to be more

Corresponding author:

H. Fearnbach

Email: holly.fearnbach@noaa.gov common in the summer months (Mellinger et al., 2004), supporting the belief that they migrate to warmer waters in winter (Whitehead \& Arnbom, 1987; Angliss \& Allen, 2010). In contrast, females and their associated offspring are thought to be restricted below the sub-arctic boundary at approximately $42^{\circ} \mathrm{N}$ (Best, 1979; Rice, 1989; Whitehead, 2003). Here we present observations and photographs from a winter sighting of a group of female and immature sperm whales near Koniuji Island, in the central Aleutian Islands, in the highlatitude waters of the Bering Sea. On 27 February 2008, we encountered a group of sperm whales just offshore of Koniuji Island, on the Bering Sea side of the central Aleutian Islands, at $52^{\circ} 17.8^{\prime} \mathrm{N}$ and $174^{\circ} 55.9^{\prime} \mathrm{W}$ (Figure 1 ). The sighting occurred during an acoustic trawl survey of walleye pollock (Theragra chalcogramma); http:/www.afsc.noaa.gov/REFM/Stocks/fit/ PDFS/Cruise_Report_DYo802.pdf, (Logerwell, 2008) operating from the NOAA ship 'Oscar Dyson', a $63.8 \mathrm{~m}$ research vessel with a bridge observation height of $11.8 \mathrm{~m}$. The characteristic slanted, puffy blows of the whales were first observed through hand-held $10 \times 25$ binoculars, several $\mathrm{km}$ from the ship, at 1119 Alaska Daylight Time. Weather and sighting conditions were extremely poor due to high winds ( $>25 \mathrm{kts}$ ), but we were able to observe the whales for 52 minutes in total.

The group was estimated to comprise approximately 50 individuals, with three distinct subgroups of size 10-12, 20-30 and 10-12 animals, respectively. Photographs were taken from the ship using digital SLR cameras with resolution of at least $10 \mathrm{MP}$, and distinct differences in the sizes of the 


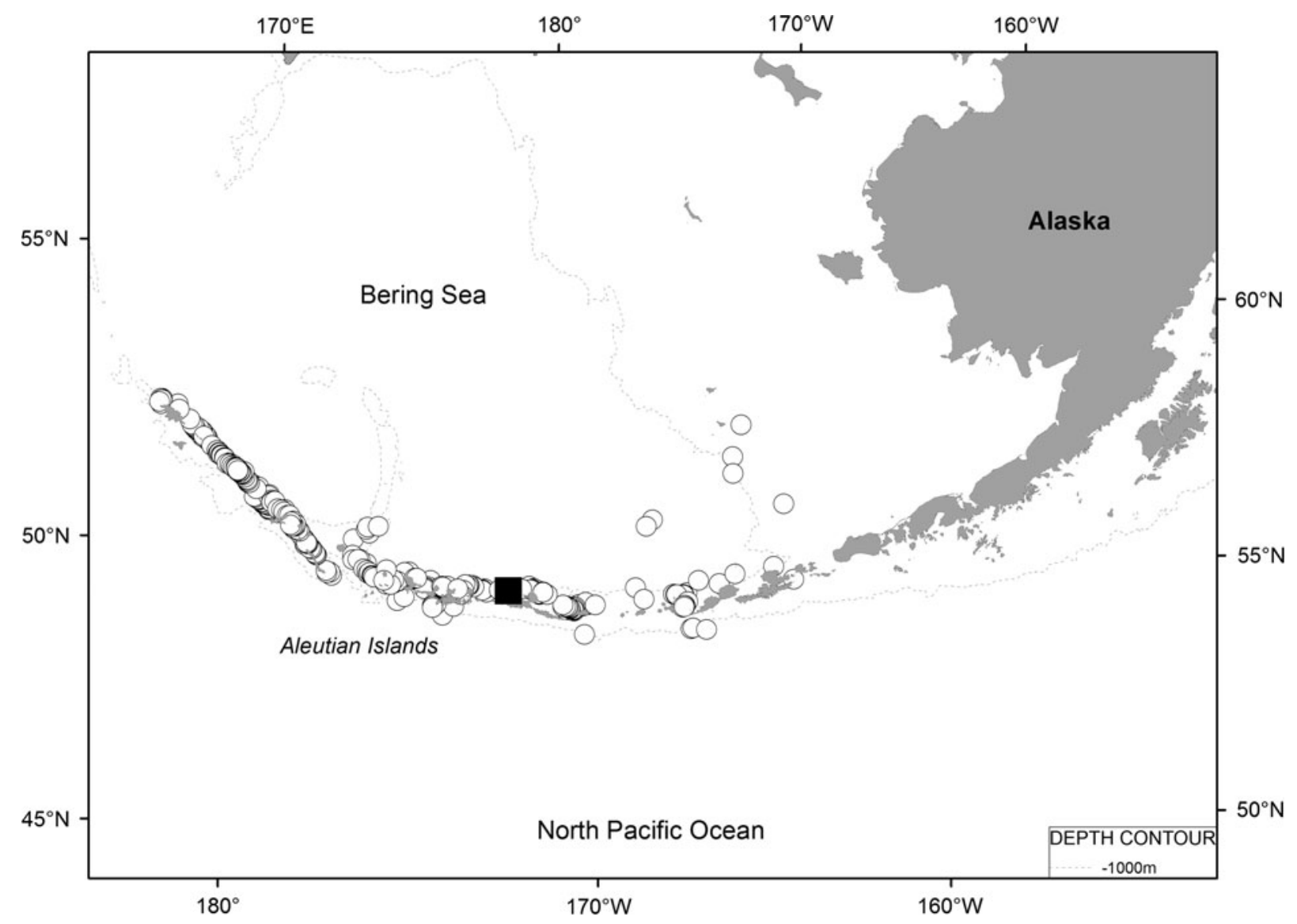

Fig. 1. Map displaying 393 sightings (open circles) of adult male sperm whales made during 12 cetacean sightings surveys along the Aleutian Islands in the summers of 2001-2007 and 2009-2010 (e.g. Zerbini et al., 2007); summer surveys occurred between the months of June and August and only large adult male sperm whales were observed. Also shown is the winter sighting (closed square) of an apparent mixed group of female and immature sperm whales of varying size and age, all smaller than adult males.

animals were apparent from the photographs (Figure 2). Although we can present no genetic data or direct anatomical observations to confirm the sex of the observed animals, we believe that this sighting was a mixed group of female and immature sperm whales for the following reasons. The group comprised larger animals, which we assumed to be adult females, with closely-associated smaller animals, presumed to be immature whales. Adult males can easily be distinguished from both females and sub-adult males in the field due to substantial differences in size $(16 \mathrm{~m}$ on average for males compared with $11 \mathrm{~m}$ for females; Rice, 1989) and a large crease on the top of the head at the transition between the nose and the trunk (Whitehead, 2003). We have extensive experience observing males during summer surveys around the Aleutian Islands (as well as females/immatures in tropical regions), and although whales of various sizes were present in all three subgroups we observed, none appeared large enough to be adult males. Furthermore, several acoustic targets that were detected by the survey's quantitative echosounding system (Simrad ER60), as the group dove in the vicinity of the ship were probably whales of varying sizes, including one measuring approximately $9 \mathrm{~m}$ and another measuring approximately $6 \mathrm{~m}$. This is consistent with the size range of females and sub-adults (Best, 1979; Rice, 1989).

All three subgroups remained within a half to one $\mathrm{km}$ of each other and were rafting at the surface for most of the encounter. Several tightly aggregated clusters of whales were observed within the subgroups, accompanied by a high degree of social contact. Sideways, partial fluking was observed in association with whales during apparent social behavior (e.g. rolling and body contact), but no high fluking for deep dives were recorded. Multiple dives of short duration were observed throughout the encounter (associated with shallow fluking), and only one dive of approximately 20 minutes duration was recorded when the whales were not observed at the surface. No directional travel was apparent as all subgroups resurfaced within several hundred metres of their initial dive location. All three subgroups appeared to alternate time spent at the surface, and several young animals (less than half the length of the accompanying adult) were observed logging by themselves at the surface for short periods while the adults were diving. In contrast, during extensive summer sighting surveys over ten years along the Aleutian Islands (e.g. Zerbini et al., 2007), we have observed sperm whales on 393 occasions, all involving much larger adult males (Figure 1). In general, most of these sightings were of solitary individuals (median group size $=1$ ), although whales were sometimes encountered at relatively high density in loose aggregations, and dive times were generally longer than 40 minutes. An additional five sperm whales were observed the following day, 28 February 2008, approximately $114 \mathrm{~km}$ away from the sighting of the females and immatures. The ship did not approach the whales, but the individuals were 

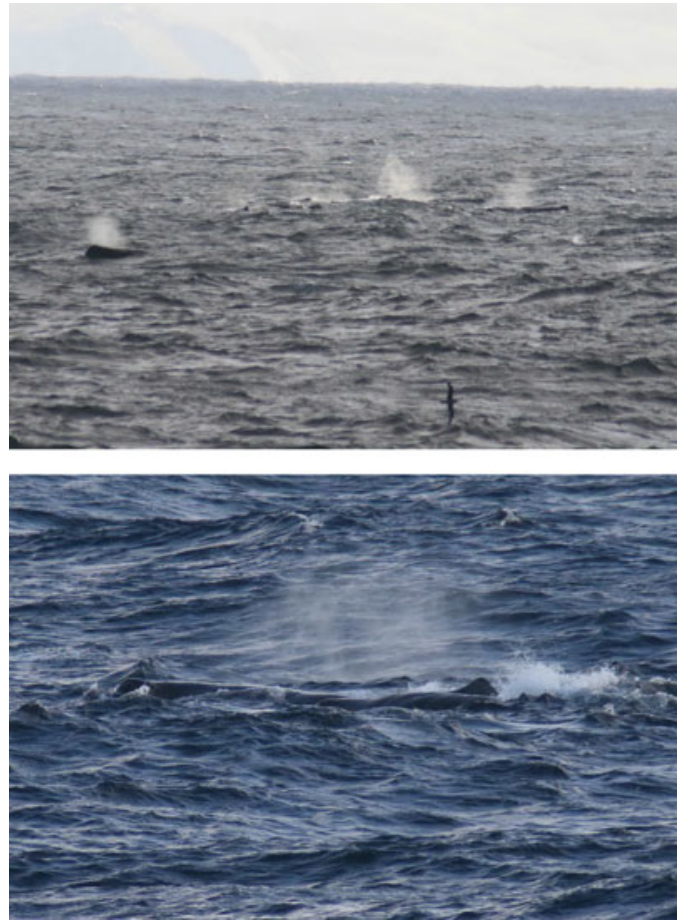

Fig. 2. Top: photograph of rafting members of a subgroup of sperm whales of varying size. Bottom: photograph of a cluster of two animals, a probable female and smaller immature sperm whale in tight association.

scattered in distribution $\left(\sim_{1} \mathrm{~km}\right.$ separation $)$ and appeared to be large adult males.

This sighting represents rare winter observations of sperm whales from the Aleutian Islands, where poor weather typically constrains sighting surveys, but it is not the only record of female and immature sperm whales from this area. Both Berzin \& Rovnin (1966) and Nishiwaki (1966) discussed seasonal distribution patterns of sperm whales on whaling grounds and reported that groups of females and immatures were observed along the Aleutian chain and in the Bering Sea, with several records of sperm whales (all age-classes and sexes) overwintering in the high-latitude waters of the western Aleutians. Berzin \& Rovnin (1966) reported that sperm whales could be found regularly in highlatitudes during the winter, specifically mentioning an observation of 80-100 animals in the Aleutians in January 1964, and Berzin (1971) documented a mixed group of females and immatures in the Aleutians in early March. Together with these earlier reports, our recent sighting confirms that groups of female and immature sperm whales are not necessarily confined to lower-latitudes of the North Pacific.

The Aleutian Islands' ecosystem is extremely productive and supports one of the world's largest fisheries. Peak areas of productivity are found on the northern (Bering Sea) side of the Aleutian chain, where upwelling, a result of the northern movement of nutrient-rich water funnelling through the passes, enhances productivity (Ladd et al., 2005). Sperm whale distribution in general has been found to be positively correlated with areas of upwelling (Jaquet, 1996) and steep topography (Berzin \& Rovnin, 1966; Jaquet \& Whitehead, 1996), which create a habitat that is extremely favourable for cephalopods, the primary prey item for female and immature sperm whales (Kawakami, 1980; Jaquet, 1996; Waring et al., 2001; Jaquet \& Gendron, 2002; Ruiz-Cooley et al.,
2004). This encounter occurred on the nutrient-rich northern side of the Aleutian chain, adjacent to a young volcano with steep associated topography. Depths at the start of the encounter were approximately $1300 \mathrm{~m}$, quickly dropping to $1500 \mathrm{~m}$ before exceeding depths recorded by the depthsounder $(1500 \mathrm{~m})$. The extremely productive area appears to offer suitable habitat for sperm whales, and adult males are regularly sighted in these areas during the summer (Figure 1).

However, it is notable that no groups of females and immatures have been observed during these recent summer sighting surveys, despite extensive survey effort and regular sightings of adult males. This contrasts with historic whaling data, which documented catches of sperm whales of both sexes, including pregnant females, in all months of whaling above $50^{\circ} \mathrm{N}$ (March-October) (Mizroch \& Rice, 2006, appendix), in both the Gulf of Alaska and along the western Aleutians and off the coast of Kamchatka (S.A. Mizroch, unpublished data). This apparent change in the occurrence of mixed groups of females and immatures may represent a depletion due to whaling (e.g. Berzin, 2008); a re-distribution as a result of past whaling (e.g. Whitehead et al., 1997); a response to changes in prey resources (e.g. Whitehead, 1996; Jaquet \& Gendron, 2002; Jaquet et al., 2003), possibly due to shifts in water temperature (Nishiwaki, 1966); or perhaps a response to increasing predation pressure by killer whales, Orcinus orca (e.g. Pitman et al., 2001). The large group size observed in this encounter is a common trait for mammals occurring in areas of increased predation risk (Alexander, 1974), and risk of predation by killer whales has been suggested to be a major factor influencing group size for sperm whales (Jaquet \& Gendron, 2009). A relatively high abundance of mammal-eating 'transient' killer whales regularly use the coastal waters of the Aleutian Islands during summer (Zerbini et al., 2007; Durban et al., 2010); although their relative winter abundance is unknown. Springer et al. $(2003,2008)$ have suggested an increase in killer whales in coastal waters of the far North Pacific in recent decades, similar to that which has been documented in the coastal north-eastern Pacific (Ford et al., 2007), which may represent a strong selective force on the distribution of vulnerable sperm whale mixed schools (Pitman et al., 2001). If this is the case, presumably adult males are large enough to avoid much predation risk, or have other social and feeding constraints against forming large groups.

\section{ACKNDWLEDGEMENTS}

We thank the crew of the NOAA R/V 'Oscar Dyson' for ship piloting and photographic contributions; and Libby Logerwell for her support as Chief Scientist on-board. We also thank Tamara Mills, a USFWS seabird observer on the cruise, who contributed useful photographs and observations from the sighting, and Sarah Mesnick and Phil Clapham for input on the manuscript. This work was conducted under NMFS Permit: 782-1719.

\section{REFERENCES}

Alexander R.D. (1974) The evolution of social behavior. Annual Reviews of Ecological Systems 5, 325-383.

Angliss R.P. and Allen B.M. (2010) Sperm whale (Physeter macrocephalus): North Pacific stock. Alaska marine mammal stock assessments, 
2009. US Department of Commerce, NOAA Technical Memo, NMFS-AFSC-206, 276 pp.

Berzin A. (1971) Kashalot (the sperm whale). Yablokov A.V. (ed.). Translated from Russian by E. Hoz and Z. Blake, Jerusalem, Israel Program for Scientific Translations. Available from the US Department of Commerce, National; Technical Information Service, Springfield, VA. 394 pp.

Berzin A. (2008) The truth about Soviet whaling: a memoir. Marine Fisheries Review 70, 1-59.

Berzin A.A. and Rovnin A.A. (1966) The distribution and migration of whales in the northeastern part of the Pacific, Chuckchee and Bering Seas. In Panin K.I. (ed.) Soviet research on marine mammal in the Far East. Vladivostok: Izvestia TINRO, pp. 103-136.

Best P.B. (1979) Social organization in sperm whales, Physeter macrocephalus. In Winn H.E. and Olla B.L. (eds) Behavior of marine animals. Volume 3. New York: Plenum, pp. 227-289.

Durban J., Ellifrit D., Dahlheim M., Waite J., Matkin C., BarrettLennard L., Ellis G., Pitman R., LeDuc R. and Wade P. (2010) Photographic mark-recapture analysis of clustered mammal-eating killer whales around the Aleutian Islands and Gulf of Alaska. Marine Biology doi 10.1007/s00227-010-1432-6.

Ford J.K.B., Ellis G.M. and Durban J.W. (2007) An assessment of the potential for recovery of west coast transient killer whales using coastal waters of British Columbia. Canadian Science Advisory Secretariat Research Document 2007/088. http://www.dfo-mpo.gc.ca/ csas/Csas/Publications/ResDocsDocRech/2007/2007_088_e.htm.

Gero S., Gordon J., Carlson C., Evans P. and Whitehead H. (2007) Population estimate and inter-island movement of sperm whales, Physeter macrocephalus, in the Eastern Caribbean Sea. Journal of Cetacean Research and Management 9, 143-150.

Jaquet N. (1996) How spatial and temporal scales influence understanding of sperm whale distribution: a review. Mammal Review 26, 51-65.

Jaquet N. and Gendron D. (2002) Distribution and relative abundance of sperm whales in relation to key environmental features, squid landings and the distribution of other species in the Gulf of California, Mexico. Marine Biology 141, 591-601.

Jaquet N. and Gendron D. (2009) The social organization of sperm whales in the Gulf of California and comparisons with other populations. Journal of the Marine Biological Association of the United Kingdom 89, 975-983.

Jaquet N., Gendron D. and Coakes A. (2003) Sperm whales in the Gulf of California: residency, movements, behavior, and the possible influence of variation in food supply. Marine Mammal Science 19, 545-562.

Jaquet N. and Whitehead H. (1996) Scale-dependent correlation of sperm whale distribution with environmental features and productivity in the South Pacific. Marine Ecology Progress Series 135, $1-9$.

Kawakami T. (1980) A review of sperm whale food. The Scientific Reports of the Whales Research Institute, Tokyo, Japan 32, 199-218.

Ladd C., Hunt Jr, G.L., Mordy C.W., Salo S.A. and Stabeno P.J. (2005) Marine environment of the eastern and central Aleutian Islands. Fisheries Oceanography 14, 22-38.

Logerwell L. (2008) DY0802 Cruise Report: echo integration-trawl survey of walleye pollock in the central Aleutian Islands. Report to the Resource Ecology and Fisheries Management Division, Alaska Fisheries Science Center, http://www.afsc.noaa.gov/REFM/Stocks/fit/ PDFS/Cruise_Report_DYo802.pdf.

Mellinger D.K., Stafford K.M. and Fox C.G. (2004) Seasonal occurrence of sperm whale (Physeter macrocephalus) sounds in the Gulf of Alaska, 1999-2001. Marine Mammal Science 20, 48-62.
Mizroch S.A. and Rice D.W. (2006) Have North Pacific killer whales switched prey species in response to depletion of great whale populations? Marine Ecology Progress Series 310, 235-246.

Nishiwaki M. (1966) Distribution and migration of the larger cetaceans in the North Pacific as shown by Japanese whaling results. In Norris K.S. (ed.) Whales, dolphins and porpoises. Berkeley, CA: University of California Press, pp. 171-191.

Pitman R.L., Ballance L.T., Mesnick S.I. and Chivers S.J. (2001) Killer whale predation on sperm whales: observations and implications. Marine Mammal Science 17, 494-507.

Rice D.W. (1989) Sperm whales (Physeter macrocephalus). In Ridgway S.H. and Harrison R. (eds.) Handbook of marine mammals. London: Academic Press, pp. 177-233.

Ruiz-Cooley R.I., Gendron D., Aguíniga S., Mesnick S. and Carriquiry J.D. (2004) Trophic relationships between sperm whales and jumbo squid using stable isotopes of C and N. Marine Ecology Progress Series $277,275-283$.

Springer A.M., Estes J.A., Van Vliet G.B., Williams T.M., Doak D.F., Danner E.M., Forney K.A. and Pfister B. (2003) Sequential megafaunal collapse in the North Pacific Ocean: an ongoing legacy of industrial whaling? Proceedings of the National Academy of Sciences of the United States of America 100, 12223-12228.

Springer A.M., Estes J.A., Van Vliet G.B., Williams T.M., Doak D.F., Danner E.M. and Pfister B. (2008) Mammal-eating killer whales, industrial whaling, and the sequential megafaunal collapse in the North Pacific Ocean: a reply to the critics of Springer et al., 2003. Marine Mammal Science 24, 414-442.

Waring G.T., Hamazaki T., Sheehan D., Wood G. and Baker S. (2001) Characterization of beaked whale (Ziphiidae) and sperm whale (Physeter macrocephalus) summer habitat in shelf-edge and deeper waters off the northeast US. Marine Mammal Science 17, 703-717.

Whitehead H. (1996) Variation in the feeding success of sperm whales: temporal scale, spatial scale and relationship to migrations. Journal of Animal Ecology 65, 429-438.

Whitehead H. (2003) Sperm whale societies; social evolution in the ocean. Chicago: University of Chicago Press.

Whitehead H. and Arnbom T. (1987) Social organization of sperm whales off the Galapagos Islands, February-April 1985. Canadian Journal of Zoology 65, 913-919.

Whitehead H., Christal J. and Dufault S. (1997) Past and distant whaling and the rapid decline of sperm whales off the Galapagos Islands. Conservation Biology 11, 1387-1396.

Whitehead H., Coakes A., Jaquet N. and Lusseau S. (2008) Movements of sperm whales in the tropical Pacific. Marine Ecology Progress Series $361,291-300$

and

Zerbini A.N., Waite J.M., Durban J.W., Dahlheim M.E. and Wade P.R. (2007) Estimating abundance of killer whales in the nearshore waters of the Gulf of Alaska and Aleutian Islands using line-transect sampling. Marine Biology 150, 1033-1045.

\section{Correspondence should be addressed to:}

H. Fearnbach

National Marine Mammal Laboratory

Alaska Fisheries Science Center

National Marine Fisheries Service

National Oceanic and Atmospheric Administration

7600 Sand Point Way NE

Seattle, WA 98115, USA

email: holly.fearnbach@noaa.gov 